\title{
Dermatophytosis due to Microsporum nanum infection in a canine
}

\section{Dermatofitose por Microsporum nanum em um canino}

\author{
Marilia Avila Valandro ${ }^{1 *}$; João Paulo da Exaltação Pascon²; \\ Maria Lígia de Arruda Mistieri²; Irina Lubeck ${ }^{2}$
}

\begin{abstract}
Miscrosporum nanum is a dermatophyte found in swine that causes non-pruritic lesions with desquamation, alopecia, and circular characteristics. M. nanum infection in dogs is rare and poorly understood in terms of its epidemiological and clinical features, and its therapeutic response. The present report describes a case of dermatophytosis due to M. nanum in a Dogo Argentino breed of dog that was used for wild boar hunting. The dermatophytosis presented with hypotrichosis, erythema, and non-pruritic desquamation in the back of the neck and chest area. The dermatophytosis was responsive to systemic treatment with itraconazole and topical (miconazole 2\%) for 60 days. Thus, we conclude that the practice of hunting wild boar should be considered as a possible source of infection of M. nanum in the reported dog. The M. nanum infection showed clinical features that were similar to the lesions observed in swine, except for the absence of the circular pattern, and showed a good clinical response to the therapy. Finally, M. nanum should be considered as an etiologic agent of dermatophytosis in dogs that in some manner have had direct contact with domestic or wild swine.
\end{abstract}

Key words: Dermatophytes. Dog. Therapy.

\section{Resumo}

O Miscrosporum nanum é um dermatófito encontrado em suídeos, promovendo lesões não pruriginosas, com características descamativas, alopécicas e circulares. A infecção de cães é rara e pouco compreendida em seus aspectos epidemiológicos, clínicos e terapêuticos. O presente relato tem por objetivo descrever um caso de dermatofitose por M. nanum em um cão Dogo Argentino, utilizado na prática de caça à javali, apresentando hipotricose, eritema e descamação não pruriginosa da região dorsal do pescoço e tórax, responsivo ao tratamento sistêmico com itraconazol, associado ao tópico (miconazol 2\%), durante 60 dias. Desta forma, concluímos que a prática de caça à suínos selvagens deve ser considerada a possível fonte de infecção de $M$. nanum no cão relatado, o qual apresentou características clínicas semelhantes às lesões observadas em suínos, exceto pela ausência do padrão circular, com boa resposta clínica à terapia empregada. Por fim, o M. nanum deve ser considerado como agente etiológico da dermatofitose em cães que, de alguma forma, possuam contato direto com suídeos domésticos ou selvagens.

Palavras-chave: Dermatófitos. Cão. Terapia.

\footnotetext{
${ }^{1}$ M.e em Ciência Animal, Universidade Federal do Pampa, UNIPAMPA, Campus Uruguaiana, RS, Brasil. E-mail: mavalandro@ gmail.com

2 Profs., Adjunto, Curso de Medicina Veterinária, UNIPAMPA, Campus Uruguaiana, RS, Brasil. E-mail: joaopascon@unipampa. edu.br; malimistieri@gmail.com; irinalubeck@unipampa.edu.br

* Author for correspondence
} 


\section{Introduction}

Dermatophytosis is a fungal disease of the keratinized tissues (skin, hair, and nails) of humans and animals, and has a variable incidence according to the geography, climate, and animal husbandry techniques. The fungi involved in this disease are classified into three genera, namely, Epidermophyton, Microsporum, and Trichophyton (BERNARDO et al., 2005; CHERMETTE et al., 2008; SEKER; DOGAN, 2011; BARSIRIJAHROMI, 2012). M. canis is responsible for most clinical cases of dermatophytosis in dogs and cats (BERNARDO et al., 2005; SEKER; DOGAN, 2011; BARSIRI-JAHROMI, 2012).

M. nanum is a dermatophyte that is more adapted to swine species, suggesting that direct contact with this species is the main source of M. nanum infection in humans and animals (AJELLO et al., 1964; ROLLER; WESTBLOM, 1986). In dogs, the occurrence of $M$. nanum infection is rare, and the clinical manifestations of such an infection have been reported in a clinical study (MUHAMMED; MBOGWA, 1974) and in studies of the prevalence of $M$. nanum in the cultivated hair of dogs and cats with suspected dermatophytosis (BERNARDO et al., 2005; SEKER; DUGAN, 2011). No report has been published on this infection in dogs in Brazil.

The main clinical characteristics of dermatophytosis lesions due to M. nanum infection include circular alopecia with raised edges and desquamation in swine (ROLLER; WESTBLOM, 1986; CHERMETTE et al., 2008), humans (ROLLER; WESTBLOM, 1986; YERGA et al., 2007), and dogs (MUHAMMED; MBOGWA, 1974; SEKER; DUGAN, 2011).

Although contact between dogs and swine is unlikely given the current commercial rearing practices for swine, illegal rearing activities and wild boar hunting practices, which are escalating in Brazil, may allow for contact between dog and swine species and possible infection. Here we report the occurrence of dermatophytosis due to M. nanum infection in a canine used for wild boar hunts.

\section{Case report}

A seven-month-old female Dogo Argentino breed of dog presented with non-pruritic alopecia with crusts and erythema in the dorsal region of the neck and chest, sternum, and pelvic limb. The clinical and physical characteristics of this dog were within the standards of the breed.

A fungal culture of hair and scabs was carried out in a petri dish containing the selective media Mycobio $^{\circledR} \quad$ (Himedia $^{\circledR}$ Laboratories, Mumbai, India) and incubated for three weeks at $25-28^{\circ}$ C. The presence of fungal growth was evaluated daily, and colonies with a cotton wool and powdery appearance were used for subsequent culture in Sabouraud agar. Microscopic analysis confirmed the production of small pear-shaped macroconidia with 1 to 3 septa, consistent with a diagnosis of $M$. nanum infection (CRUZ, 2010).

Dermatophytes are a group of fungi that have the ability to use keratin as a substrate. The infection of the keratinized tissue is termed "tinha" or ringworm (BERNARDO et al., 2005; CHERMETTE et al., 2008; BARSIRI-JAHROMI, 2012). These fungi can be found in companion, production, or wild animals (SPIEWAK; SZOSTAK, 2000).

The incidence of $M$. nanum infection in companion animals is low. In a survey conducted in Portugal by Bernardo et al. (2005) involving 234 animals (144 dogs and 90 cats) with dermatophytosis, only $1.4 \%$ of dogs and $2.2 \%$ of cats had this fungus. In another survey conducted by Seker and Dogan (2011) in Turkey, fungal cultures of the hair of 198 dogs and 164 cats with suspected dermatophytosis were performed, and M. nanum growth was present in only $5.4 \%$ of the dog samples and $18.1 \%$ of the cat samples. However, the prevalence of $M$. nanum infection in companion animals might be underestimated because typically in clinical 
practice the identification of the fungal species is only performed for the therapeutic diagnosis of mycosis (BERNARDO et al., 2005).

In humans, $M$. nanum infection is associated with the handling of swine. All reports of dermatophytosis due to $M$. nanum in humans involve workers and residents of rural areas where swine farming is common. Sometimes the infected animals show ringworm lesions; however cases have been described in which the fungus was isolated from apparently healthy pigs. Ajello et al. (1964) and Roller and Westblom (1986) isolated M. nanum from soil cultures in places of swine rearing, confirming the existence of saprophytes of active growth in the soil and sporulated forms of the fungus. Dermatophytosis due to $M$. nanum has been described as a common zoonosis of rural workers (ROLLER; WESTBLOM, 1986; SPIEWAK; SZOSTAK, 2000; YERGA et al., 2007).

Direct contact with a contaminated environment or animal is the main source of infection in humans and animals (CHERMETTE et al., 2008). Although, in general, dogs do not maintain direct contact with domestic swine, some dogs are used in the practice of hunting wild boar. Thus, this activity is a possible source of infection.

The overall presentation of "tinha" in animals and humans, as reported by Muhammed and Mbogwa (1974), Mós et al. (1978), Roller and Westblom (1986), Yerga et al. (2007), and Cermette et al. (2008), was similar to the findings upon physical examination of the canine in our case report. That is, the infection presented as hypotrichosis with erythema and desquamation. The previous studies added that in humans and swine, pruritus is usually absent, and that the lesions, multiple or single, are typically located in the cranial part of the body and head.

In humans, Roller and Westblom (1986) reported the successful topical treatment of three patients using miconazole ointment for six weeks or clotrimazole topical cream and oral griseofulvin for six weeks. In dogs, however, no specific treatment for dermatophytosis due to $M$. nanum infection has been reported. The treatment we used for our reported canine was similar to that used by Chermette et al. (2008) in the treatment of $M$. canis infections, which consisted of systemic oral itraconazole at $10 \mathrm{mg} \mathrm{kg}^{-1}$ every 24 hours and topical 2\% miconazole shampoo in two weekly baths. This therapy was effective, with complete remission of the lesions within 30 days of use, and a negative culture after this period. The treatment was continued for another 30 days in accordance with the recommendations of Chermette et al. (2008) for dermatophytosis.

The conditions of our reported case suggest that the direct contact with wild swine (wild boar) during hunting was the source of the M. nanum infection that caused dermatophytosis. Similarly, the locations and characteristics of the skin lesions, notwithstanding the lack of a circular pattern, were similar to the lesions that have been described in swine. Finally, our treatment of the infection was successful and can be recommended in other cases of $M$. nanum infection in dogs.

\section{References}

AJELLO, L.; VARSAVSKY, E.; GINTHER, O. J.; BUBASH, G. The natural history from Microsporum nanum. Mycologia, New York, v. 56, n. 6, p. 873-884, 1964.

BARSIRI-JAHROMI, S. Epidemiological trends in zoophilic and geophilic fungi in Iran. Clinical and Experimental Dermatology, London, v. 38, n. 1, p. 1319, 2012.

BERNARDO, F.; LANÇA, A.; GUERRA, M. M.; MARTINS, H. M. Dermatophytes isolated from pet, dogs and cats, in Lisbon, Portugal (200-2004). Revista Portuguesa de Ciências Veterinárias, Lisboa, v. 100, n. 553-554, p. 85-88, 2005.

CHERMETTE, R.; FERREIRO, L.; GUILLOT, J. Dermatophytoses in animals. Mycopathologia, Dordrecht, v. 166, n. 5-6, p. 385-405, 2008.

CRUZ, L. C. H. da. Micologia veterinária. 2. ed. Rio de Janeiro: Revinter, 2010. 384 p. 
MÓS, E. N.; PAULA, C. R.; MOTT JUNIOR, L. M. Dermatomicose por Microsporum nanum em criação de suínos. Revista da Faculdade de Medicina Veterinária e Zootecnia da Universidade de São Paulo, São Paulo, v. 15, n. 2, p. 159-160, 1978.

MUHAMMED, S. I.; MBOGWA, S. Isolation of $M$. nanum from a dog with skin lesions. Veterinary Record, London, v. 25-26, n. 95, p. 573-573, 1974.

ROLLER, J. A.; WESTBLOM, T. U. Microsporum nanum in hog farmers. Journal of American Academy of Dermatology, Schaumburg, v. 15, n. 5, p. 935-939, 1986.
SEKER, E.; DOGAN, N. Isolation of dermatophytes from dogs and cats with suspected dermatophytosis in Western Turkey. Preventive Veterinary Medicine, Westlake, v. 98, n. 1, p. 46-51, 2011.

SPIEWAK, R.; SZOSTAK, W. Zoophilic and geophilic dermatophytosis among farmers and non-farmers in eastern Poland. Annals of Agricultural Environmental Medicine, Lublin, v. 7, n. 2, p. 125-129, 2000.

YERGA, A. M. L.; RODRÍGUEZ-NEVADO, I. M.; FERNÁNDEZ-RECIO, J. M.; ÁlVAREZ, A. J. C.; FÉRNANDEZ-DURÁN, D. A.; ECHEVARRI, E. G. Infección cutânea por Microsporum nanum. Semergen, Madrid, v. 33, n. 3, p. 159-60, 2007. 